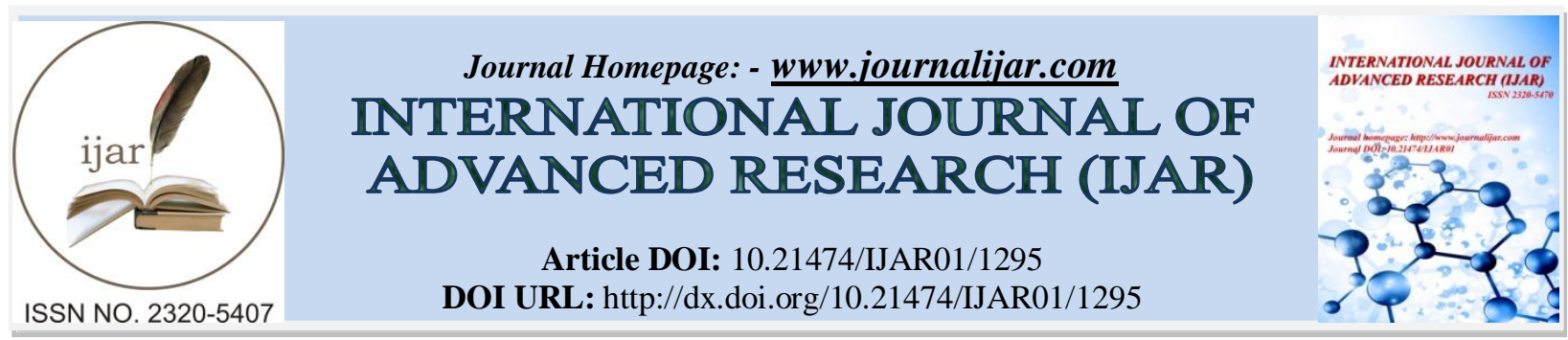

RESEARCH ARTICLE

\title{
STUDIES OF BIOENERGY COMPOUNDS AND MOLECULAR CHARACTERIZATION OF BOTRYOCOCCENE SYNTHASE GENE FROM BOTRYOCOCCUS BRAUNII KUTZING.
}

\author{
T. Sangeetha ${ }^{1}$, G.K. Saravanan ${ }^{2},{ }^{*}$ S. Elumalai ${ }^{3}$ and D. Bhuvana ${ }^{4}$. \\ 1. Department of Chemistry, Presidency College (Autonomous), Chennai - 600005. \\ 2. Department of Plant Biology and Plant Biotechnology, Presidency College (Autonomous), Chennai - 600005 . \\ 3. Department of Biotechnology, University of Madras, Guindy campus, Chennai- 600025. \\ 4. Department of Biotechnology, Valliammal College for Women, Chennai- 600102.
}

\section{Manuscript Info}

\section{Manuscript History}

Received: 10 June 2016

Final Accepted: 11 July 2016

Published: August 2016

Key words:-

Botryococcus braunii, Botryococcene,

FAME, Biofuel, Biochemical

\section{Abstract}

Advanced generation biofuel production from microalgae Botrycoccus braunii was investigated. The micro alga Botryococcus was first discovered and described by Kutzing in 1849 which has drawn more attention in the recent decades due to high accumulation of different types of hydrocarbons. The microalga Botryococcus braunii showed the growth kinetic and biochemical parameters include dry biomass, carbohydrate, protein and lipids. The extraction of fatty acid methyl esters (FAME) from the biomass of the microalga B. braunii were analyzed for biofuel compounds using gas chromatography mass spectrometry (GC-MS) and Fourier transform infra-red spectroscopy (FT-IR) the percentage of FAME were resulted. The presence of esters, alkanes and alkenes confirms the presence of hydrocarbons from the FAME. The phylogenetic relationship of the microalga Botryococcus braunii was analyzed by ClustalW and Neighbor joining method in MEGA5 program using the botryococcene gene. The dendrogram clearly shows that the isolated microalgal strain belongs to Botryococcus braunii.

Copy Right, IJAR, 2016,. All rights reserved.

\section{Introduction:-}

The population explosion along with economic growth in the developing countries like India and China has major focus on transportation which led to rapid increase in demand for energy all over the world. The biofuel has the efficiency to become a sustainable and renewable energy because of the carbon released into air by combustion of fossil fuels can be recycled in the form of biochemical and biomasses.

The micro alga Botryococcus has drawn more attention in recent decades due to high accumulation of different types of hydrocarbons (Borowitzka, 1988). The Botryococcus braunii Kutzing is a green colonial micro alga occurs in fresh water, brackish water, reservoirs and ponds which are cosmopolitan in nature (Metzger and Largeau, 2005; Banerjee et al., 2002).

The hydrocarbon fraction of Botryococcus braunii has three different types of races such as (A, B and L) Squalene synthase, lycopadiene and botryococcene. The Botryococcus race B from Sumatran crude oil comprises of $1.4 \%$ of botryococcene and available as completely hydrogenated form (Moldowan and Seifert, 1980). The Brauniiceae, a 
new isoprenoid hydrocarbon $\left(\mathrm{C}_{33} \mathrm{H}_{54}\right)$ membrane fused botryococcene family was the first time reported from the Berkeley strains of B. braunii and constituted about 28-34 \% from dry biomass (Huang et al., 1987). Both oleic acid and palmitic acid are the fundamental components of lipid and as a precursor for hydrocarbon accumulation in $B$. braunii (Yamaguchi et al., 1987).

\section{Materials and Methods:-}

Fresh water sample collection:-

Sample collection were made by random sampling method from fresh water bodies at Mylapore and Triplicane temple tanks Chennai, Tamil Nadu, India. The predominant criterion for sample collection was the evident abundance of microalgae in the water, $1000 \mathrm{~mL}$ of water samples was collected from the each sampling site.

\section{Shake Flask Culture:-}

At this stage $25 \mathrm{~mL}$ culture in Erlenmeyer Flasks was shaken manually twice a day in a full strength medium where sub cultured for further analysis. Most samples were enriched by this way for dominant strains until the samples taken for serial dilution or streaking on to solid media used for strain isolation. The isolated microalgae were studied under a compound microscope (OLYMPUS CH20i) and photographs were taken. The micro algae were identified based on the morphological characteristic features using 'Microalgae Identification for Aquaculture', by Rosen (1990).

\section{Growth kinetics of the microalga Botryococcus braunii:-}

The green microalga Botryococcus braunii isolated and pure culture was maintained in the Algal culture collection laboratory, Department of Plant Biology and Plant Biotechnology, Presidency College (Autonomous), Chennai600005. The microalga Botryococcus braunii was allowed to grown in a Bold Basal Medium (BBM) liquid broth (400 mL in 11 Erlenmeyer flask with $4 \%$ inoculums) and incubated for 16 days under 12:12 hrs of dark and light (Crompton $40 \mathrm{~W}$, Cool day light $6500 \mathrm{~K}$ at an intensity of 2000 lux.) at room temperature $\left(28^{\circ} \mathrm{C}\right)$. The optical absorbance values were analyzed for 16 days at $680 \mathrm{~nm}$ in an UV-Vis. Spectrophotometer (Hitachi U-2900). The Growth kinetics $(\mathrm{K})$ and generation times $(\mathrm{G})$ of all the microalga Botryococcus braunii was calculated by the following equations 1 and 2 (Qin, 2005).

Equation 1:

Where,

$$
K=(\log O D f-\log O D i) / T \times 3.322
$$

ODf : final optical density, ODi : initial optical density, $\mathrm{T}$ : time in days

Equation 2: Following equation was used for Calculation of generation time (G) in days:

\section{Harvest and estimation of dry biomass:-}

$$
G=0.301 / K
$$

The biomass after in vitro mass cultivation was harvested by centrifugation at $8000 \mathrm{rpm}$ for $5 \mathrm{~min}$. at $20^{\circ} \mathrm{C}$. The concentrated biomass in the pellet was obtained and mixed using a cyclomixer and transferred to a watch glass, which was then incubated in an incubator at $35^{\circ} \mathrm{C}$ for overnight. The dry biomass was wiped using a sharp sterilized surgical blade and weighed gravimetrically using an electronic weighing balance.

\section{Biochemical constituents:-}

\section{Estimation of total Chlorophyll $a$ and Chlorophyll $b$}

The green photosynthetic pigment Chlorophyll a and Chlorophyll b were estimated by Jeffrey and Humphery (1975) method and its equation given below.

$$
\begin{aligned}
& \text { Chlorophyll } a=11.93 \mathrm{E} 664-1.93 \mathrm{E} 647 \mu \mathrm{gmL}^{-1} \\
& \text { Chlorophyll } b=20.36 \mathrm{E} 647-5.50 \mathrm{E} 664 \mu \mathrm{gmL}^{-1}
\end{aligned}
$$

The absorbance values at 664 and $647 \mathrm{~nm}$ were recorded daily for about 16 days using a UV-Vis. Spectrophotometer.

Estimation of total carotene:-

The total carotene content of the green microalga Botryococcus braunii was determined everyday up to 16 days based on the formula is given below.

$$
\text { Carotene }(\mu \mathrm{g} / \mathrm{mL})=\mathrm{A}_{450} \mathrm{~nm} \times 25.2
$$




\section{Extraction and estimation of carbohydrate:-}

The total carbohydrate of green algae B. braunii was determined based on the method well defined by Dubois et al. in the year 1956 (Phenol Sulphuric acid method). About $100 \mu \mathrm{l}$ of the crude sample was subjected to treat with 5\% phenol and $2.5 \mathrm{~mL}$ of Conc. Sulphuric acid. Then the whole content was incubated for 10-15 min. at room temperature. Then the optical absorbance values were measured at $490 \mathrm{~nm}$ using a UV-Vis. Spectrophotometer. The total carbohydrate content was determined by comparing the absorbance values with the standard graph using Dglucose as a known carbohydrate sample.

\section{Extraction and estimation of protein:-}

The estimation of protein of green algae B. braunii, in this present study was done based on the method described by Bradford (1976). The protein content of the unknown sample was determined in comparison with the standard graph of the known sample. The standard graph for protein was constructed using Bovine serum albumin as a standard known protein. About $1 \mathrm{~mL}$ of the crude sample used to determine the total protein content with $5 \mathrm{~mL}$ of the Bradford reagent. After incubation for $15 \mathrm{~min}$. the content was subjected to determine the absorbance values at 595 $\mathrm{nm}$ in a UV-Vis. Spectrophotometer.

\section{Extraction and estimation of lipid:-}

The total lipid constituent of green algae $B$. braunii was determined based on the method described by Folch et al. in 1957. A $6 \mathrm{~mL}$ of chloroform and methanol (2:1 ratio) was mixed with the extract and vortexed for 3 min. at room temperature. The extract was then centrifuged at $8000 \mathrm{rpm}$ for $5 \mathrm{~min}$. The resultant liquid phase was washed with 6 $\mathrm{mL}$ of $0.9 \%$ of $\mathrm{NaCl}$ and vortexed for $5 \mathrm{~min}$. The entire content was then centrifuged at $2000 \mathrm{rpm}$ for $5 \mathrm{~min}$. which resulted to form two distinct phases. The upper phase conserved due to its richness in lipid and the lower aqueous phase was discarded. The total lipid content was determined gravimetrically after the complete evaporation of the solvent (Upper phase).

Extraction and analysis of fatty acid methyl esters (FAME) by gas chromatography:-

About $20 \mathrm{~mL}$ of green algae B. braunii sample was subjected to direct Transesterification. About $1 \mathrm{~mL}$ of reagent 1 was poured to the fresh algal samples and vortexed for 5-10 sec. using a cyclomixer. The mixture was incubated in a water bath at $100^{\circ} \mathrm{C}$ for $5 \mathrm{~min}$. and again vortexed for 5-10 sec. Then after incubated at $100^{\circ} \mathrm{C}$ for $25 \mathrm{~min}$. reagent 2 was added and vortexed for $5-10 \mathrm{~min}$. followed by thermal incubation at $80^{\circ} \mathrm{C}$ and rapidly cooled down to $4^{\circ} \mathrm{C}$. Reagent 3 was added the mixture and mixed gently up to $10 \mathrm{~min}$. Two phases were seen blatantly from which, the lower phase was conserved. To the content $3 \mathrm{~mL}$ of reagent 4 was added followed by mixing for $5 \mathrm{~min}$. and obtained upper phase was removed. The lower phase rich in fatty acid methyl esters were stored in a vial at $4^{\circ} \mathrm{C}$ in a refrigerator.

The tranesterified fatty methyl esters were analyzed with the help of a gas chromatography equipped with flame ionization detector (FID) (Perkin Elmer, USA). A SP-2560 column (100 m $\times 0.25 \mathrm{~mm} \mathrm{I}$. D., $0.20 \mu \mathrm{m})$ (Sigma, Germany) along with standard fatty acid Supelco 37 Component FAME mix from Supelco (Bellefonte, PA, USA) was employed. About $5 \mu \mathrm{l}$ of the sample was injected and the $\mathrm{GC}$ conditions were injector temperature: $260^{\circ} \mathrm{C}$; Column temperature: $140^{\circ} \mathrm{C}$ and detector temperature: $260^{\circ} \mathrm{C}$. Helium was used as a carrier gas with the flow rate of $1 \mathrm{~mL} / \mathrm{min}$. The unknown FAMEs were determined in comparison with the retention times of the standard FAMEs (Supelco) using a mass spectra from NIST library.

\section{Fourier transforms infra red spectrometric (FT-IR) analysis of FAME:-}

The FAME sample were analyzed under infra red (Perkin Elmer model spectrum - I PC). The FT-IR spectra with the resolution of $4 \mathrm{~cm}^{-1}$, Scan Number: 3 were performed after the evaporation of the lipid fraction on Thalium bromide tablets. The FT-IR spectrums of all the FAME samples were obtained as a percentage of transmission ranged from $450 \mathrm{~cm}^{-1}$ to $\quad 4000 \mathrm{~cm}^{-1}$.

\section{Molecular identification of Botryococcus braunii:- Isolation of RNA:-}

About $300 \mu \mathrm{l}$ of the culture was ground into fine powder in liquid nitrogen using a mortar and pestle. A $2 \mathrm{~mL}$ of solution I was added while grinding to make homogenous mixture and allowed to thaw completely with intermittent grinding. Then $800 \mu \mathrm{l}$ of nuclease free water was added by mixing and grinding. The whole content was transferred to $2 \mathrm{~mL}$ microcentrifuge tubes and kept undisturbed place for $5 \mathrm{~min}$. at room temperature. Chloroform $(200 \mu \mathrm{l})$ was added to each tube and vortexed briefly for less than 10 seconds and kept undisturbed for $10 \mathrm{~min}$. at room 
temperature. Then the whole mixture was allowed to centrifuge for $10 \mathrm{~min}$. at $4^{\circ} \mathrm{C}$ and the upper aqueous phase was transferred into to fresh microcentrifuge tubes. Then about 0.6 volumes of isopropanol were added and vortexed briefly less than 10 seconds and left for $10 \mathrm{~min}$. at room temperature. Then after centrifugation at $13,000 \mathrm{rpm}$ for 10 min. at $4^{\circ} \mathrm{C}$ the supernatant was discarded and the obtained pellet with RNA was washed with $70 \%$ ethanol, air dried and dissolved in $50 \mu \mathrm{l}$ of DEPC-treated water. The extracted RNA was separated and analyzed using $1.5 \%$ Agarose in submarine gel electrophoresis.

Solution I:- Phenol saturated with tris (hydroxymethyl) aminomethane buffer to a pH of 6.7 \pm 0.2 . To this sodium dodecyl sulphate [SDS; $0.1 \%(\mathrm{w} / \mathrm{v})]$, sodium acetate [NaOAc; $0.32 \mathrm{M}(\mathrm{w} / \mathrm{v})]$ and ethylenediaminetetra acetic acid (EDTA; 0.01 $\mathrm{M}$ final concentration from a stock solution of $0.5 \mathrm{M}, \mathrm{pH} 8.0$ ) were added.

\section{cDNA synthesis:-}

The first strand of cDNA was synthesized using $3 \mu \mathrm{l}$ of RNA sample with SMART IV oligonucleotide and CDS/3' PCR primer $1 \mu \mathrm{l}$ each. After thorough mixing the content was incubated at $72^{\circ} \mathrm{C}$ for $2 \mathrm{~min}$. and cooled on ice for 2 min. After spinning briefly, 5X first strand buffer $(2 \mu \mathrm{l})$, DTT $(20 \mathrm{mM})(1 \mu \mathrm{l})$, dNTP mix $(10 \mathrm{mM})(1 \mu \mathrm{l})$ and Power script RT (1 $\mu \mathrm{l})$ were added and mixed. After incubation for $1 \mathrm{hr}$ at $42^{\circ} \mathrm{C}$, the content was stored at $-80^{\circ} \mathrm{C}$ in an ice.

\section{PCR amplification:-}

A PCR was performed in a total volume of $30 \mu \mathrm{l}$ containing $15 \mu \mathrm{l}$ master mixture, $1 \mu \mathrm{l}$ of $\mu \mathrm{M}$ each of primer and $1 \mu \mathrm{l}$ of cDNA template. PCR conditions were as follows: denaturation at $94^{\circ} \mathrm{C}$ for $5 \mathrm{~min}$; 35 cycles of $94^{\circ} \mathrm{C}$ for 1 min, primer-specific annealing temperature at $45 \mathrm{sec}$ and extension at $72^{\circ} \mathrm{C}$ for $1 \mathrm{~min}$, and a final extension at $72^{\circ} \mathrm{C}$ for 5 min. The PCR products were resolved by electrophoresis in a $1 \%$ agarose gel in $1 \times$ TAE buffer. The gels were prestained with $10 \mathrm{mg} / \mathrm{mL}$ ethidium bromide.

\section{Gene sequence and submission to NCBI GenBank:-}

Amplified PCR product purified using Qiaquick PCR purification kit (QIAGEN, USA). Sequencing reactions were carried out in both directions using same forward and reverse primers used for amplification with BigDye Version 3.1 kit (Applied Bio-systems) on an ABI-PRISM 3730 DNA Sequencer (Applied Bio-systems). Ambiguous sequences from the base called sequences were corrected with Chromas (Version 2.01) and the sequences were assembled with Bio-Edit (Version 7.0.9.0). The search for sequence homolog of potential gene product was made using the BLASTn and BLASTx program (NCBI).

\section{Results:-}

\section{Microscopical identification of Botryococcus braunii:-}

In the present investigation, Botryococcus braunii was microscopically identified from the collected fresh water samples. The identified Botryococcus braunii was presented in Fig.1. The identification of microalgae was based on their distinctive characteristics (Butcher, 1959; Carmelo and Grethe, 1997) and the instruction for microscopical identification was suggested by the Krishnamurthy Institute of Algology, Chennai.

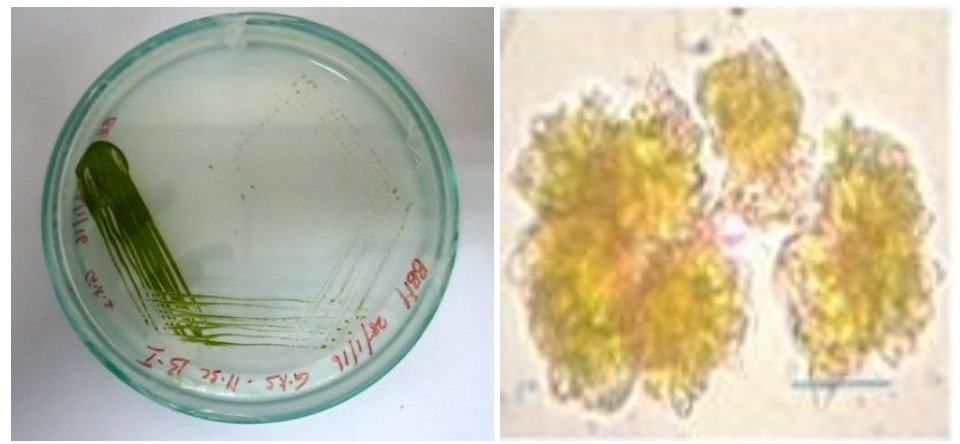

Fig. 1:- Botryococcus braunii.

\section{Growth kinetics of the microalga Botryococcus braunii:-}

The growth curve has blatantly shown that the log phase was initiated from the second day and attained stationary phase from third day till the sixteenth day (Graph 1). The death stage was not occurred up to sixteen days instead all 
the biomass was settled at the bottom of culture flask. The microalga Botryococcus braunii attained the growth kinetic $(\mathrm{K})$ of 0.099 and the generation time $(\mathrm{G})$ was 3.09 .

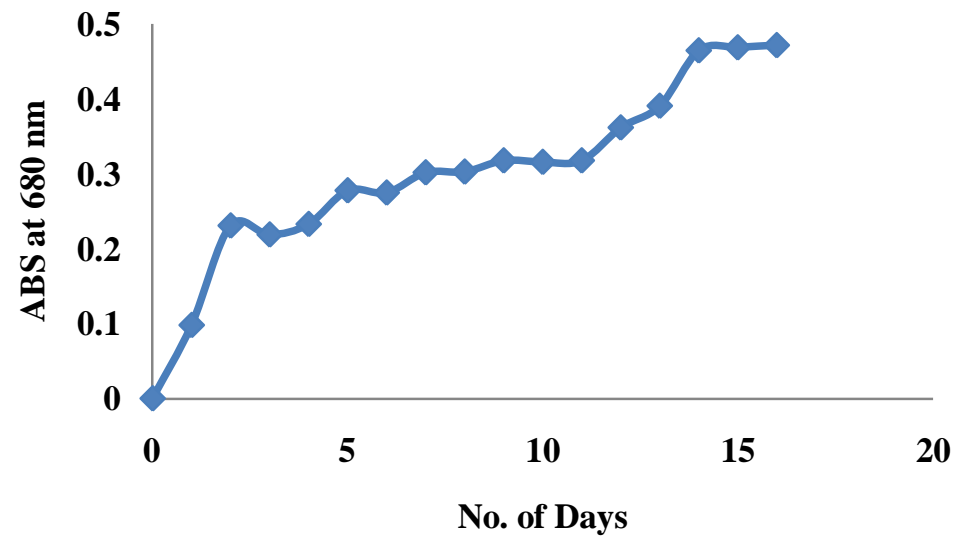

Graph 1:- Growth curve of the green microalga Botryococcus braunii.

Estimation of pigments:-

The important photosynthetic pigments of green microalgae $B$. braunii including chlorophyll a and $\mathrm{b}$ were found to be $7.09 \mu \mathrm{g} \mathrm{ml}^{-1}$ and $10.51 \mu \mathrm{g} \mathrm{ml}^{-1}$ respectively. The total carotene was found high with $18.27 \mu \mathrm{g} \mathrm{ml}^{-1}$, when compared with the chlorophyll pigments. The production of pigments seems to be correlated with the proliferation of the microalga Botryococcus braunii. Where, hike in the pigment production starts from the third day and found approximately stable in the stationary phase and propelled further during the last $14^{\text {th }}, 15^{\text {th }}$ and $16^{\text {th }}$ days (Graph 2).

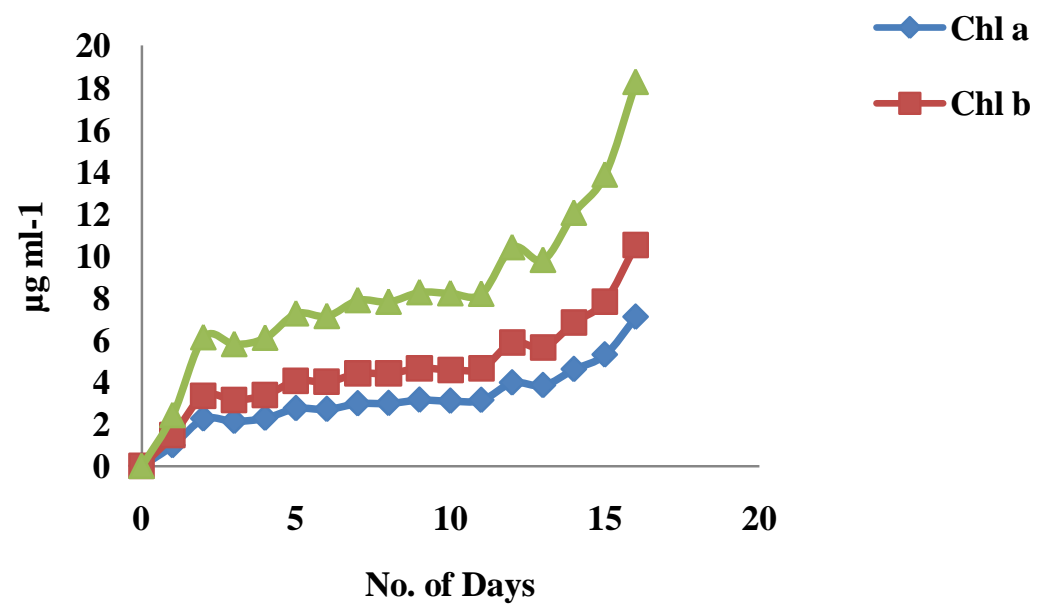

Graph 2:- The figure shows the production of the three important pigments by Botryococcus braunii

\section{Biochemical constituents:-}

After in vitro mass cultivation, the harvested biomass was dried and the dried biomass estimated in an electronic weighing balance which was about $236 \mathrm{mg} \mathrm{ml}^{-1}$. From the obtained biomass, total carbohydrate, total protein and total lipid content was estimated. The total carbohydrate content was $62.57 \mathrm{mg} \mathrm{ml}^{-1}$ which engulfs about $43.93 \%$ of total biochemical composition. The total protein comprises $10.11 \%$ of the total biochemical constituents with 14.4 $\mathrm{mg} \mathrm{ml}^{-1}$. The total lipid content was $65.46 \mathrm{mg} \mathrm{ml}-1$ and holds $45.95 \%$ of the total biochemical component (Graph 3 ). On the whole, it is evident that the lipid and carbohydrate content was produced high by the green microalga Botryococcus braunii, but the protein content was approximately and comparatively half when compared with the total lipid content. 


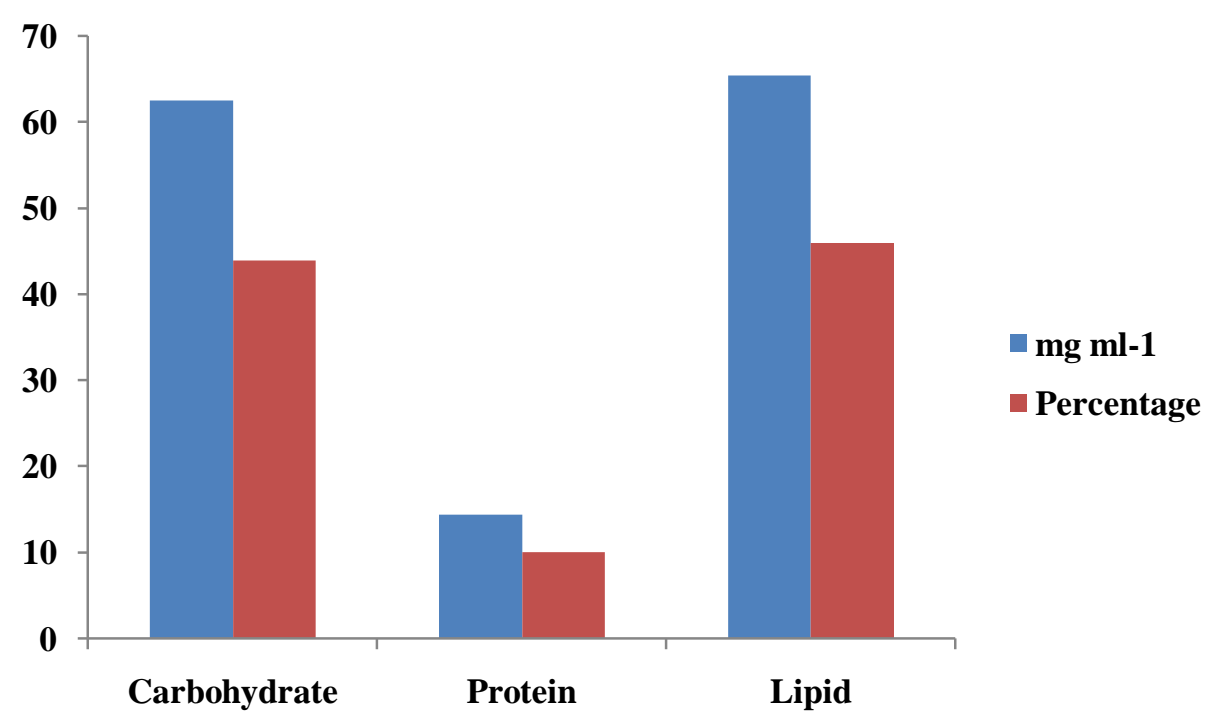

Graph 3:- Biochemical constituents of Botryococcus braunii.

Analysis of fatty acid methyl esters (FAME) by gas chromatography and mass spectrometry (GC-MS):-

The total fatty acid methyl esters obtained in the Botryococcus braunii strain was about $64.26 \%$ of the total lipid content (Fig. 5). The fatty acid methyl esters include Propanoic acid C27:0 (22.60 \%); Propanoic acid C27:0 (15.65 \%); 9-octadecenoic acid C38:0 (15.21 \%) and Carotenoic acid C27:0 (10.8\%) (Table: 1) (Graph: 4). The presence of high cetane number compounds in the FAME of Botryococcus braunii represents the occurrence of long chain fatty acids and hydrocarbon.

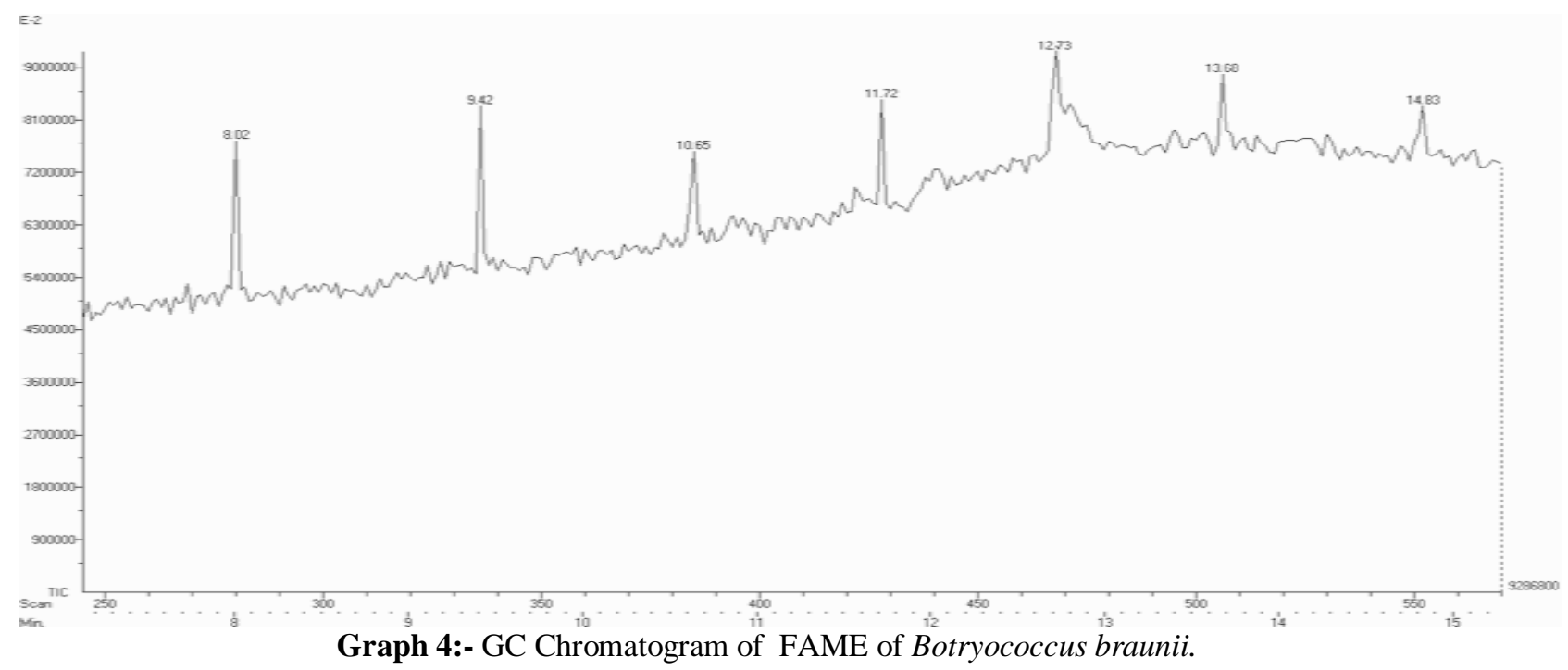


Table 1:- Some of the important hydrocarbons and its molecular structures produced by B. braunii race B (Banerjee et al., 2002)

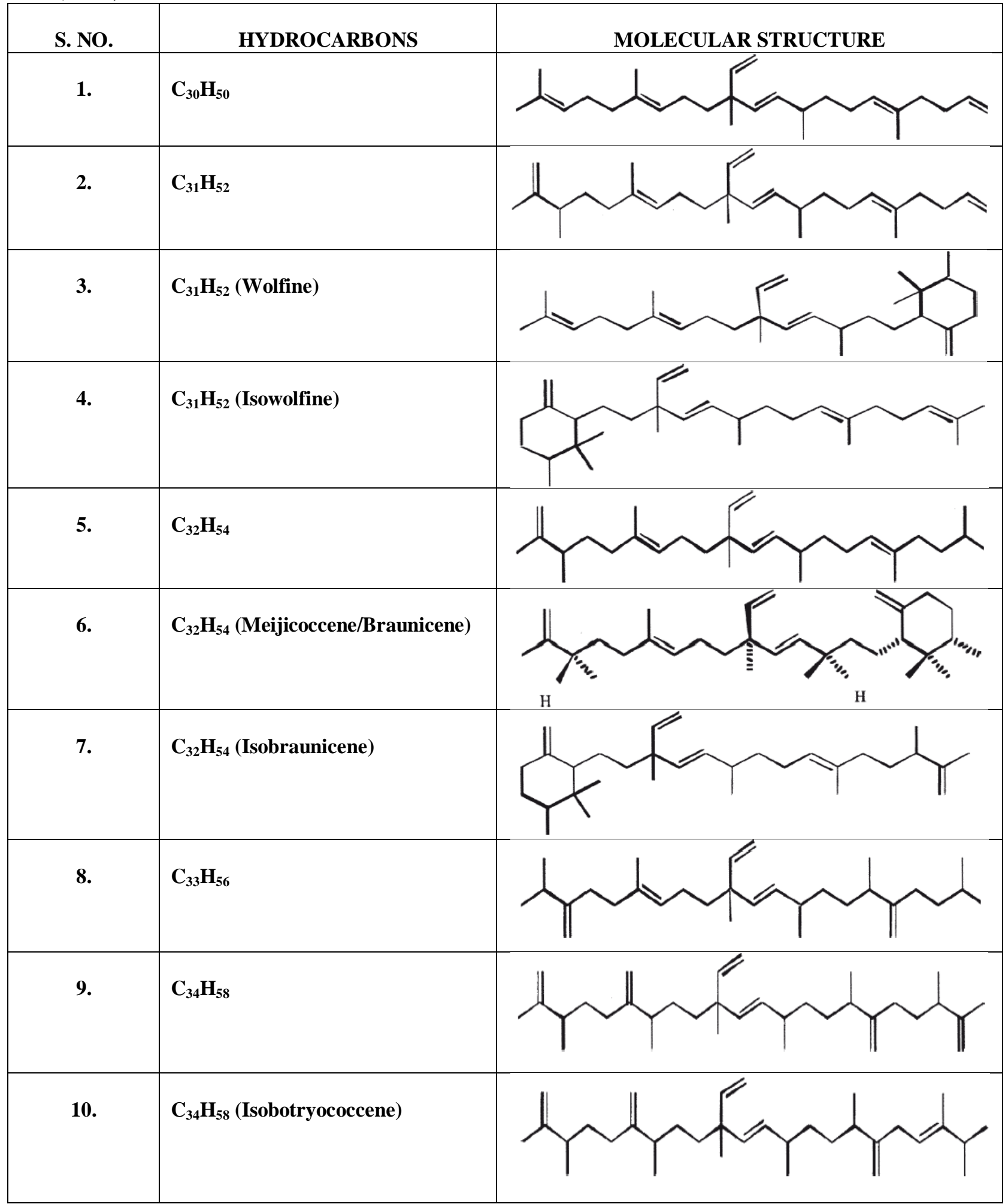




\begin{tabular}{|c|c|c|}
\hline 11. & $\mathrm{C}_{34} \mathrm{H}_{58}$ & 1 \\
\hline 12. & $\mathrm{C}_{34} \mathrm{H}_{58}$ & \\
\hline 13. & $\mathrm{C}_{34} \mathrm{H}_{58}$ & \\
\hline 14. & $\begin{array}{l}\mathrm{C}_{35} \mathbf{H}_{60} \text { (strain isolated from } \\
\text { Darwin lake, Australia) }\end{array}$ & Structure yet to be elucidated \\
\hline 15. & $\mathrm{C}_{36} \mathrm{H}_{62}$ (Darwinene) & \\
\hline 16. & $\mathbf{C}_{37} \mathbf{H}_{64}$ & \\
\hline
\end{tabular}

Fourier transforms infra red spectrometric (FT-IR) analysis of FAME:-

The alkane $(\mathrm{C}-\mathrm{H})$ and alkyne $(-\mathrm{C}=\mathrm{C}-)$ groups were determined in the FAME samples of Botryococcus braunii at $2972,2932,2887,1467,1380 \mathrm{~cm}^{-1}$ and $2194 \mathrm{~cm}^{-1}$ respectively. The presence of alkenes $(=\mathrm{C}-\mathrm{H})$ were determined by the occurrence of peak at $952 \mathrm{~cm}^{-1}$. The esters were also reported at $1308 \mathrm{~cm}^{-1}$ and as a result the FAME is rich in long chain hydrocarbon compounds (Table 2) (Graph. 5).

Table 2:- FT-IR of Functional Groups of Constituents from Botryococcus braunii.

\begin{tabular}{|l|l|l|}
\hline \multicolumn{1}{|c|}{ Peaks } & Bonds & Functional groups \\
\hline $3361 \mathrm{~cm}^{-1}$ & $\mathrm{~N}-\mathrm{H}$ & $1^{\circ}, 2^{\circ}$ amines, amides \\
\hline $2972,2932,2887 \mathrm{~cm}^{-1}$ & $\mathrm{C}-\mathrm{H}$ & Alkanes \\
\hline $2658,2413 \mathrm{~cm}^{-1}$ & $\mathrm{H}-\mathrm{C}=\mathrm{O}: \mathrm{C}-\mathrm{H}$ & Aldehydes \\
\hline $2194 \mathrm{~cm}^{-1}$ & $-\mathrm{C}=\mathrm{C}-$ & Alkynes \\
\hline $1904 \mathrm{~cm}^{-1}$ & $\mathrm{C}=\mathrm{O}$ & Carbonyls (general) \\
\hline $1648 \mathrm{~cm}^{-1}$ & $\mathrm{~N}-\mathrm{H}$ & $1^{\circ}$ amines \\
\hline $1467,1380 \mathrm{~cm}^{-1}$ & $\mathrm{C}-\mathrm{H}$ & Alkanes \\
\hline $1341 \mathrm{~cm}^{-1}$ & $\mathrm{~N}-\mathrm{O}$ & Nitro compounds \\
\hline $1308 \mathrm{~cm}^{-1}$ & $\mathrm{C}-\mathrm{O}$ & $\begin{array}{l}\text { Alcohols, carboxylic acids, esters, } \\
\text { ethers }\end{array}$ \\
\hline $1162,1130 \mathrm{~cm}^{-1}$ & C-H $-\mathrm{CH}_{2} \mathrm{X}$ & Alkyl halides \\
\hline $1001 \mathrm{~cm}^{-1}$ & $\mathrm{C}-\mathrm{N}$ & Aliphatic amines \\
\hline $952 \mathrm{~cm}^{-1}$ & $=\mathrm{C}-\mathrm{H}$ & Alkenes \\
\hline $816 \mathrm{~cm}^{-1}$ & $\mathrm{C}-\mathrm{Cl}$ & Alkyl halides \\
\hline $678,492 \mathrm{~cm}^{-1}$ & $\mathrm{C}-\mathrm{Br}$ & Alkyl halides \\
\hline
\end{tabular}




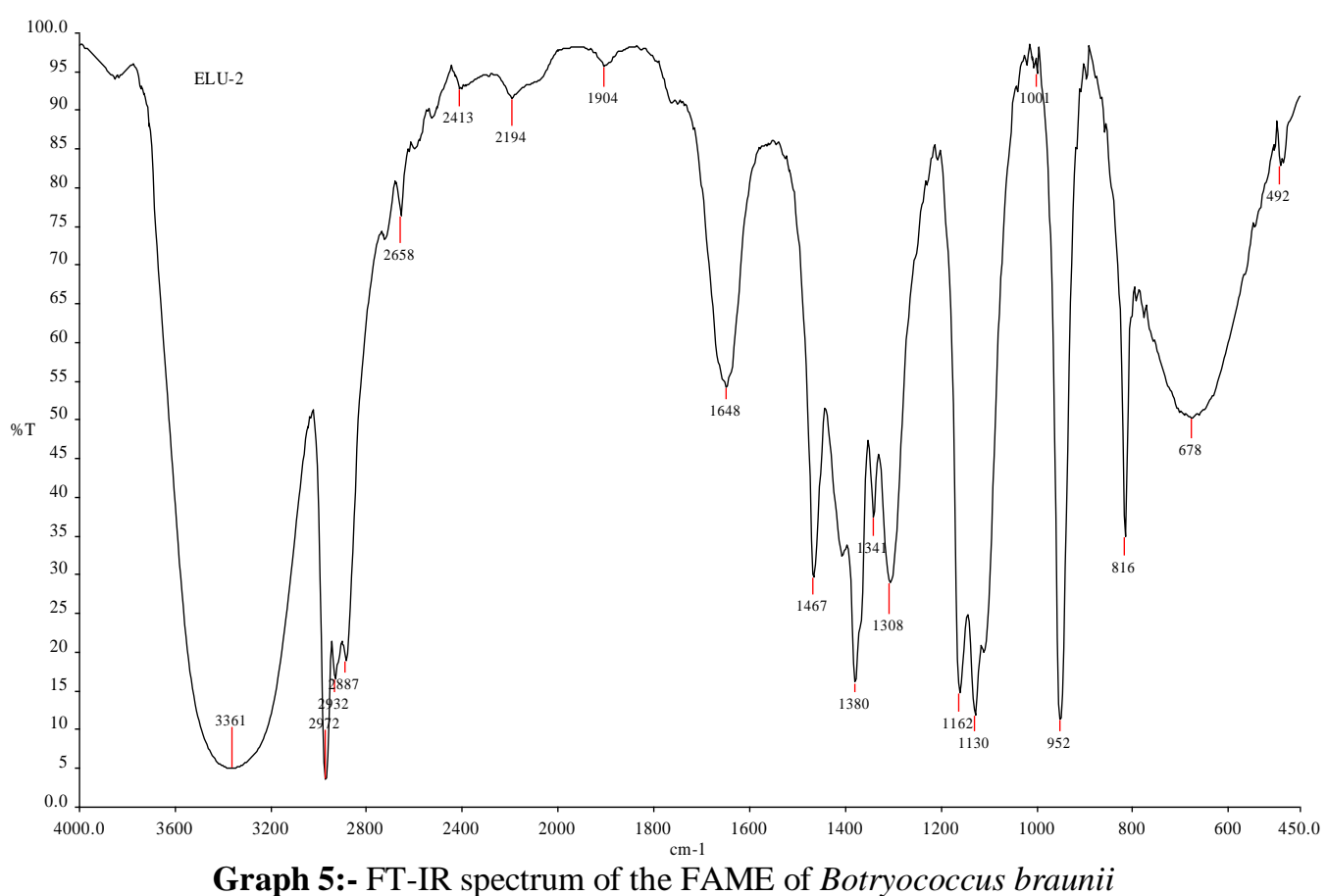

Molecular identification:-

Isolation of RNA and cDNA synthesis:-

The total RNA was extracted from the green microalga Botryococcus braunii was then separated and analyzed under submarine agarose gel electrophoresis. Two different bands in the gel shows mixed of RNA where the major RNAs are $28 \mathrm{~S}$ and $18 \mathrm{~S}$ rRNA (Fig. 2). The cDNA was synthesized using the SSL-3 primer (Table 3) already mentioned above and were qualitatively confirmed by $1.5 \%$ agarose gel electrophoresis. Where, the single band shows the cDNA synthesized and were allowed to sequence based on the Sanger's method of dideoxy sequencing (Fig. 3). The SSL-3 gene sequence was submitted to NCBI through BankIt, GenBank and the temporary BankIt submission number was retrieved (BankIt submission no. 1897142) and the accession number yet to be received.
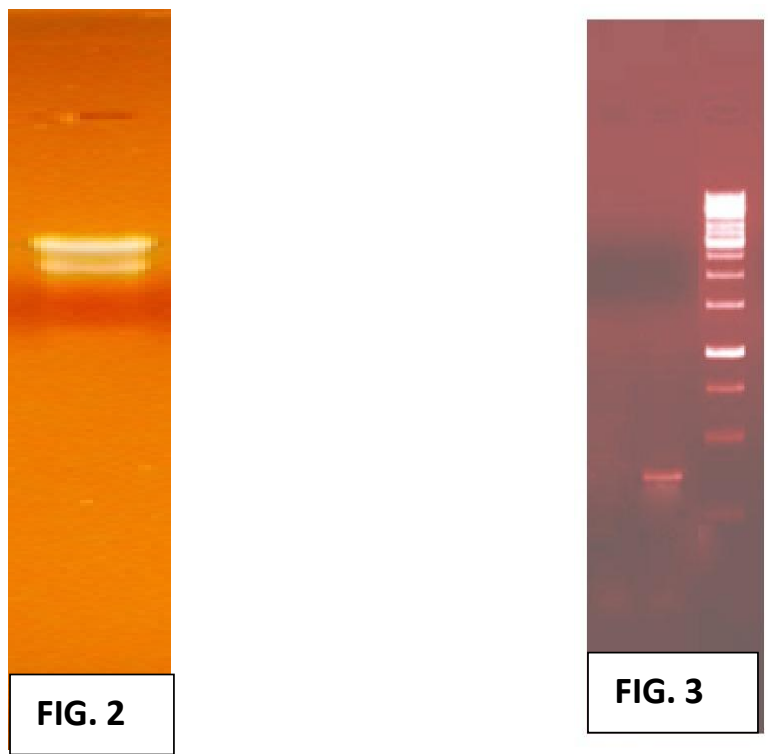

Fig. 2:- The bands in the agarose gel image showing the extracted RNA from Botryococcus braunii.

Fig. 3:- The single band in lane 1 shows the cDNA of the gene Botryococcene synthase 
Table 3:- Primer details used for amplification.

\begin{tabular}{|l|l|l|l|}
\hline Gene (Accession no) & Primer sequence (5' -3') & $\begin{array}{c}\text { Annealing } \\
\text { temperature } \\
{ }^{\circ} \mathbf{C}\end{array}$ & Size (bp) \\
\hline $\begin{array}{l}\text { Squalene synthase-like } \\
\mathbf{3} \text { (HQ585060) }\end{array}$ & $\begin{array}{l}\text { F:TCGGGAAGTCTTGCAGCACC } \\
\text { R:AAGCACCCTTAGCTGAAACCTT }\end{array}$ & 54.9 & 250 \\
\hline
\end{tabular}

\section{Phylogenetic analysis:-}

The dendrogram represents the phylogenetic relationship of the microalga Botryococcus braunii with other group of organisms using the gene SSL-3 (Squalene Synthase like - 3 or Botryococcene synthase) (Fig. 4). In which, the SP2 is the sequenced SSL-3 gene of Botryococcus braunii placed in a separate clade along with the green microalgae. Another phylogenetic tree was constructed using the NCBI BLAST Pair wise alignment of Neighbour joining method with maximum sequence difference of 0.005 . Where, a unique clade was formed (1Cl|Query_224699) between the similar strains of Botryococcus braunii and which molecularly confirms that the gene belongs to SSL-3 and the strain belongs to Botryococcus braunii (Fig. 5).

The evolutionary history was inferred using the UPGMA method. The optimal tree with the sum of branch length = 2.34483239 is shown. The percentage of replicate trees in which the associated taxa clustered together in the bootstrap test (1000 replicates) is shown above the branches. The tree is drawn to scale, with branch lengths in the same units as those of the evolutionary distances used to infer the phylogenetic tree. The evolutionary distances were computed using the Poisson correction method [3] and are in the units of the number of amino acid substitutions per site. The rate variation among sites was modeled with a gamma distribution (shape parameter $=1$ ). The analysis involved 12 amino acid sequences. All positions containing gaps and missing data were eliminated. There were a total of 408 positions in the final dataset. Evolutionary analyses were conducted in MEGA5.

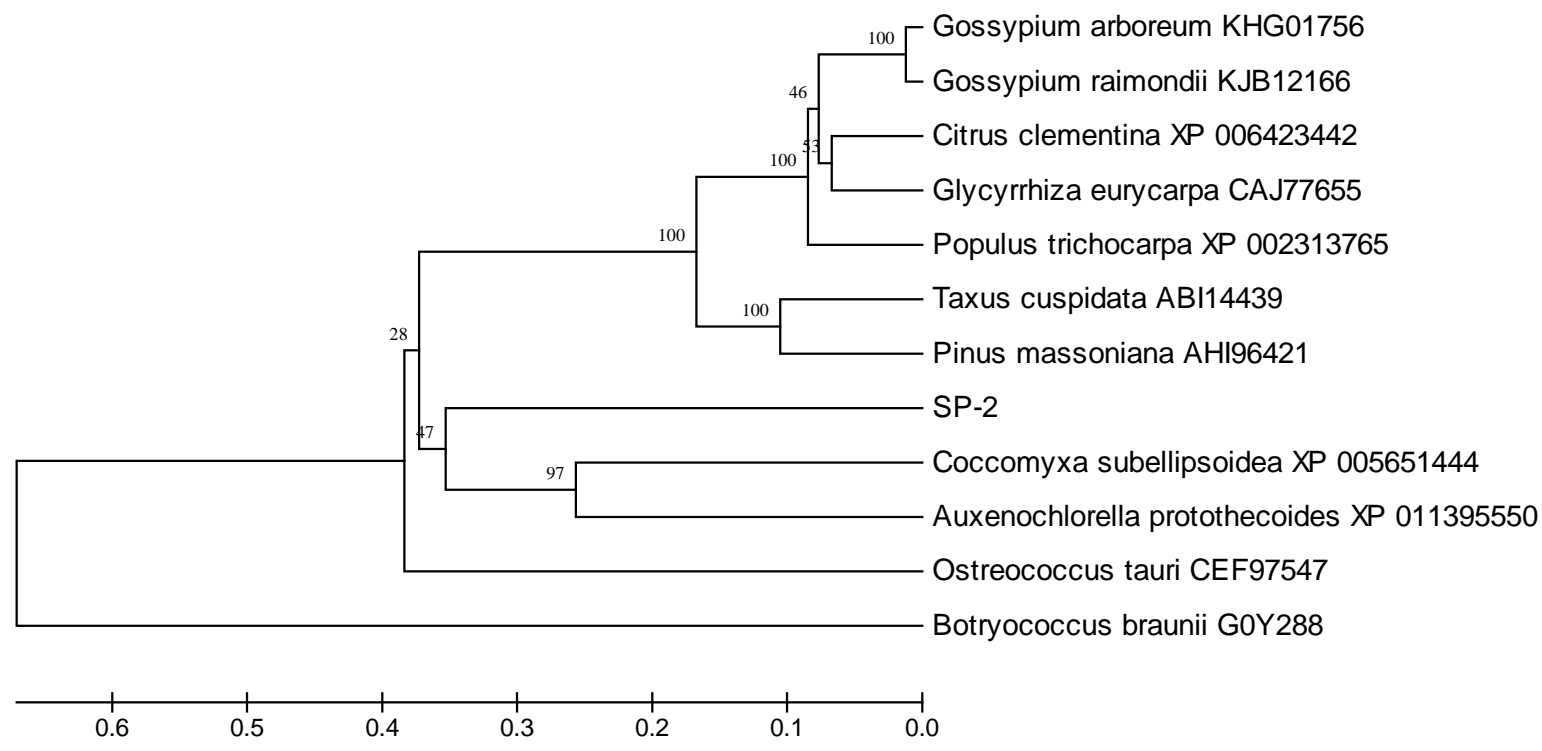

Fig. 4:- Evolutionary relationships of Botryococcene synthase (SSL-3) obtained from Botryococcus braunii. 


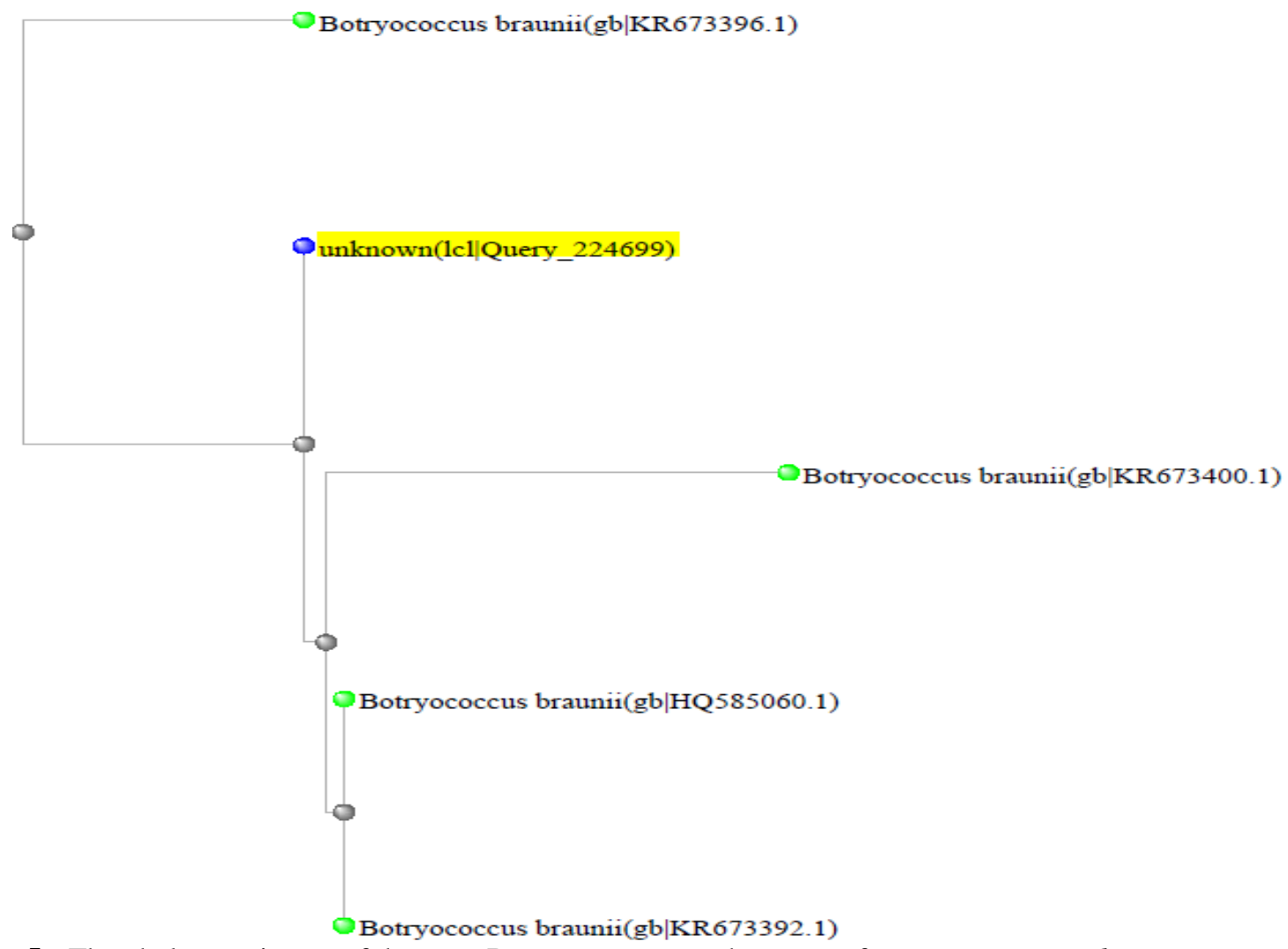

Fig. 5:- The phylogenetic tree of the gene Botryococcene synthase gene from Botryococcus braunii constructed using NCBI.

\section{Discussion:-}

Mogilevskii and his associates investigated the microbial Petroleum prospecting incited the interest of petroleum geochemists worldwide. Initially proposed and applied the microbial surveys in the USSR (Mogilevskii, 1940). It has been shown that out of 20 microbial anomalies, 16 were proved successful drilling. These investigations initiated the interest of petroleum geochemists worldwide. In USA microbial prospecting surveys showed positive correlation about $85.7 \%$ respectively (Sealy, 1974). In oil field of microbial survey at USA indicated that good contrast nearby dry area (Miller, 1976).

Microalgae are the major sources of lipids in lacustrine and marine environments. Volkman et al. (1989) provides a review of some recent advances in our knowledge of the wide variety of lipid types that have been isolated from microalgae with an emphasis on those likely to be useful biomarkers for identifying sources of organic matter in sediments. In many numbers of microalgae species were found among these Botryococcus sp. is a remarkable due to its capacity for synthesizing major amount of unsaturated hydrocarbons (up to $75 \%$ from dry biomass). Similar to those from oil deposits (Moldowan and Seifert, 1980), physical and chemical analysis of kerogen from boghead coals identified in different geographical regions, presented a similar composition with B. braunii hydrocarbons.

Over recent years, many new compounds have been identified in sediments deposited in marine and lacustrine environments. Despite the fact that our knowledge of algal lipids is still far from comprehensive, microalgal sources have now been identified for many of the lipids that are widely distributed in recent sediments (Volkman et al., 1995; Conte et al., 1994). Volkman et al. (1998) provides a review of some recent advances in our knowledge of the wide variety of lipid types that have been isolated from microalgae with an emphasis on those likely to be useful biomarkers for identifying sources of organic matter in sediments. From the obtained biomass, total carbohydrate, total protein and total lipid content was estimated. The total carbohydrate content was $62.57 \mathrm{mg} \mathrm{ml}^{-1}$ which engulfs about $43.93 \%$ of total biochemical composition. The total protein comprises $10.11 \%$ of the total biochemical constituents with $14.4 \mathrm{mg} \mathrm{ml}^{-1}$. The total lipid content was $65.46 \mathrm{mg} \mathrm{ml}-1$ and holds $45.95 \%$ of the total biochemical component (Fig. 4.3). On the whole, it is evident that the lipid and carbohydrate content was produced 
high by the green microalga Botryococcus braunii, but the protein content was approximately and comparatively half when compared with the total lipid content.

Microalgae are major source of fatty acids in most sedimentary environments. The contribution from different microalgal classes can often be discerned from characteristic differences between the distributions, especially if the positions of double bonds in polyunsaturated fatty acids are considered (Volkman and Johns, 1977). Some microalgae contain high concentrations of certain long-chain essential polyunsaturated fatty acids such as $20: 5 n-3$ and 22:6n-3 (Volkman et al., 1989). For example, marine eustigmatophytes such as Nannochloropsis spp. contain 20:5n-3 but little 22:6n-3, whereas haptophytes (prymnesiophytes) such as Pavlova spp. contain both 20:5n-3 and 22:6n-3. Chlorophytes rarely contain significant amounts of these fatty acids, but instead have a predominance of $\mathrm{C}_{18}$ polyunsaturated fatty acids such as 18:2n-6 and 18:3n-3. Dinoflagellates have high levels of 20:5n-3 and 22:6n-3 and many contain the unusual fatty acid 18:5n-3. However, the latter is not unique to dinoflagellates and has been found in algae as diverse as haptophytes, raphidophytes and some prasinophytes (Volkman et al., 1989). The total fatty acid methyl esters obtained in the Botryococcus braunii strain was about $64.26 \%$ of the total lipid content. The fatty acid methyl esters include Propanoic acid C27:0 (22.60 \%); Propanoic acid C27:0 (15.65 \%); 9-octadecenoic acid C38:0 (15.21\%) and Carotenoic acid C27:0 (10.8\%) (Table 3) (Fig.7 to 12). The presence of high cetane number compounds in the FAME of Botryococcus braunii represents the occurrence of long chain fatty acids and hydrocarbon. Fourier transform infra red spectroscopy (FT-IR) was studied in B. braunii . The presence of esters, alkanes and alkenes confirms the presence of hydrocarbons from the FAME.

Botryococcene represents a particularly diagnostic biomarker for the assessment of paleoenvironments. This $\mathrm{C}_{34}$ isoprenoidal alkane is considered to be derived from botryococcene, a compound known to exist only in Botryococcus braunii, which is widely distributed in freshwater lakes. Thus the identification of botryococcene in oils and sediments indicates the contribution of $B$. braunii to the depositional environment. However despite the quite widespread presence of Botryococcus remains in type I kerogen, this specific biomarker was only detected in a few extracts and oils, such as Sumatran oils (Seifert and Moldowan, 1985), Australian coastal bitumen (McKirdy et al., 1985) and Maoming oil shale (Brassell et al., 1986). This observation may be explained, at least in part, by the fact that of the three modern chemical races of B. braunii (A, B and L; for a review see Metzger et al., 1991), only race $B$ produces botryococcene. Indeed, the fully hydrogenated derivatives, botryococcanes and tetrametylsqualane, are specific markers of $B$. braunii which are found in petroleum and oil shales, sometimes in high amounts (McKirdy et al., 1986; Summons et al., 2002). The SSL-3 gene sequence of Botryococcus braunii was translated into amino acids and the molecular structure of the protein Botryococcene synthase (SSL-3) was predicted and illustrated. The predicted molecular structure of botryococcene synthase has shown about 14 helical structures with the absence of $\beta$-pleated sheets. The superimposed study on the obtained molecular structure of botryococcene synthase protein of Botryococcus braunii with the Human Squalene synthase protein resulted that the former protein has more conserved amino acid sequence, thus the structure resembles with the human squalene synthase protein. But there are some conformational differences in their quaternary structure.

\section{Conclusion:-}

The green microalga Botryococcus braunii has been already reported widely to be the efficient candidate for the production of biodiesel due to the high accumulation of lipid molecules. The biodiesel production from the microalga Botryococcus braunii is a cost effective, ecofriendly, efficient and intensive method for the oil production. In this present study, a new micro algal strain Botryococcus braunii was isolated from the temple tanks. The biochemical constituents and occurrence of different fatty acid methyl esters (FAME) proves the present microalgal strain Botryococcus braunii a potent candidate for the production of biodiesel.

\section{References:-}

1. Banerjee, Sharma, Chisti and Banerjee. (2002): Botryococcus braunii: A renewable source of hydrocarbons and other chemicals. Critical Reviews in Biotechnology, 22: 245-279.

2. Borowitzka. (1988): Fats, oils and hydrocarbons. In: Borowitzka, M.A. and Borowitzka, L.J. (eds.) Micro-algal biotechnology. Cambridge, Cambridge University Press, pp. 257-287.

3. Bradford, M.M. (1976): A rapid and sensitive method for the quantitation of microgram quantities of protein utilizing the principle of protein-dye binding. Anal. Biochem., 72: pp. 248-254.

4. Butcher, R.W. (1959): An introductory account of the smaller algae of the British coastal waters I. Fisheries Investigations. 74 pp. 
5. Carmelo, R.T. and Grethe, R.H. (1997): Identifying marine phytoplankton. Academic Press, San Diego.

6. Conte, Volkman and Eglinton. 1994: Lipid biomarkers of Haptophyta. In Green, J.C., and Leadbeater, B.S.C. (Eds.), The Haptophyte Algae: Oxford (Clarendon Press), 351-377.

7. Dubois, M., Gilles, K.A., Hamilton, J.K., Rebers, P.A., Smith, F. (1956): Colorimetric method for determination of sugars and related substances. Anal. Chem., 28: 350-356.

8. Folch, J., Lees, M. and Stanley, G.H.S. (1957): A simple method for the isolation and purification of total lipides from animal tissues. The Journal of Biological Chemistry 226: 497-509.

9. Huang, Perrott, Perrott, Metzger and Eglinton. (1987): Glacial-interglacial environmental changes inferred from molecular and compound-specific $\delta 13 \mathrm{C}$ analyses of sediments from Sacred Lake., Mt. Kengya. Geochim Cosmochim., 63: 1383-1404.

10. Jeffrey, S.W., Humphrey, G.F. (2005): New spectrophotometric equations for determining chlorophylla, $b$, $c_{1}$ and $c_{2}$ in higher plants, algae and natural phytoplankton.-Biochem. Physiol. Pflanz.167: 191-194, 1975.

11. McKirdy, D. M. (1985): Coorongite, coastal bitumens and their origins from the lacustrine alga Botryococcus braunii in the Western Otway Basin. In Otway 85, Earth Resources of the Otway Basin. GeolSoc Aust., Adelaide: $34-49$.

12. Metzger, P. and Largeau, C. (2005): Botryococcus braunii: A rich source for hydrocarbons and related ether lipids. Appl Microbiol Biotechnol., 66: 486-796.

13. Miller, G. H. (1976): Microbial survey helps to evaluate oil and gas. Oil and Gas Journal, 4, 192.

14. Mogilewskii, G. A. (1940): The bacterial method of prospecting for oil and natural gases: Razvedka Nedr.,12: 32-43.

15. Moldowan, J.M. and Seifert, W.K. (1980): First discovery of botryococcane in petroleum. JCS Chem Commun., 19: 912-914.

16. Moldowan, J.M., Seifert, W.K. and Gallegos, E.J. (1985): Relationship between petroleum composition and depositional environment of petroleum source rocks: AAPG Bulletin, v. 69, pp. 1255-1268.

17. Qin, J. (2005): Bio-Hydrocarbons from Algae: Impacts of temperature, light and salinity on algae growth. Rural Industries Research and Development Corporation Report. 26 pp.

18. Rosen, B.R. (1990): Biogeographic patterns: a perceptual overview. In: Myers A.A. and Giller, P.S. (eds) Analytical Biogeography. Chapman and Hall, London, pp 23-56.

19. Sealy, J. R. (1974): A geomicrobial method of prospecting for oil. Oil and Gas Journal, 8, 142-46.

20. Summons R. E, Metzger, P., Largeau, C., Murray, A. P. and Hope, J. M. (2002): Polymethylsqualanes from Botryococcus braunii in lacustrine sediments and crude oils. Org Geo chem., 33: 99-109.

21. Volkman J.K., Jeffrey S.W., Nichols, P.D., Rogers, G.I., Garland, C.D. (1989): Fatty acid and lipid composition of 10 species of microalgae used in mariculture. Journal of Experimental Marine Biology and Ecology, 128: 219-240.

22. Volkman, J. K. and Johns, R. B. (1977): The geochemical significance of positional isomers of unsaturated acids from intertidal zone sediment. Nature, 267: 693-694.

23. Volkman, J. K., Barrett, S. M., Blackburn, S. I. and Sikes, E. L. (1995): Alkenones in Gephyrocapsa oceanica: implications for studies of paleoclimate. Geochim. Cosmochim. Acta, 59: 513-520.

24. Volkman, J. K., Barrett, S. M., Blackburn, S. I., Mansour, M. P., Sikes, E. L. and Gelin, L. (1998): Microalgal biomarkers: A review of recent research developments. Organic Geochemistry, 29 (5-7 ): 1163-1179.

25. Yamaguchi, K., Nakano, H., Murakami, M., Konosu, S., Nakayama, O., Kanda, M., Nakamura, A. and Iwamoto, H. (1987): Lipid composition of a green alga, Botryococcus braunii. AgriBiol Chem., 51: 493-498. 